\title{
Knowledge, Attitude and Practices of Blood Donors toward Blood Donation
}

\author{
${ }^{1}$ Karobi Das, ${ }^{2}$ Geetanjali, ${ }^{3}$ Suchet Sachdev, ${ }^{4}$ Baljeet Kaur, ${ }^{5}$ Charan Inder Singh, ${ }^{6}$ Daiamonlang Nongbri
}

\section{ABSTRACT}

Aim: To assess the knowledge, attitude and practices of blood donors toward blood donation and to find out association of knowledge and attitude with selected demographic variables.

Materials and methods: A total of sixty (60) subjects were selected using purposive sampling technique. The knowledge, attitude, and expressed practice questionnaire, was devised and construct and content validated before usage. The study was conducted at the Department of Transfusion Medicine of a tertiary level Institute from northern India during the year 2011-2012. Paper and pencil technique was used to collect the data.

Results: Analysis of data collected revealed that $23(38.4 \%)$ of the participants had good knowledge, 21 (35\%) had average knowledge, $12(20 \%)$ had excellent knowledge and only few 04 $(6.6 \%)$ had poor level of knowledge regarding blood donation. Mean of the knowledge score was $6.21 \pm 2.3$ and the mean percentage was $51.8 \%$. Assessment of attitude revealed that majority of the participants had a strongly favorable attitude toward blood donation. Assessment of practices showed that majority $45(75 \%)$ of the donors had donated blood for almost five times. Nearly half $28(46.7 \%)$ of the donors donated blood only when they were asked for and more than half 32 (53.3\%) of donors started donating blood when they were in age group of 21 to 30 years. Regarding reasons for blood donation, exactly half $30(50 \%)$ of them donated due to altruism, and all the donors $(100 \%)$ were willing to do so in future. The demographic variables like education and occupation were found to be associated with level of knowledge and attitude toward blood donation.

Conclusion: The findings of the study revealed that blood donors had good knowledge and a positive attitude toward blood donation but majority of individuals were not donating blood regularly as volunteers.

Keywords: Knowledge, Attitude, Practices, Blood donors and blood donation.

How to cite this article: Das K, Geetanjali, Sachdev S, Kaur B, Singh Cl, Nongbri D. Knowledge, Attitude and Practices of Blood Donors toward Blood Donation. J Postgrad Med Edu Res 2014;48(3):123-127.

\footnotetext{
${ }^{1}$ Lecturer, ${ }^{2}$ Clinical Instructor, ${ }^{3}$ Assistant Professor

${ }^{4-6}$ Former Post Basic Nursing Student

${ }^{1,2,4-6}$ Department of National Institute of Nursing Education Postgraduate Institute of Medical Education and Research Chandigarh, India

${ }^{3}$ Department of Transfusion Medicine, Postgraduate Institute of Medical Education and Research, Chandigarh, India
}

Corresponding Author: Karobi Das, Lecturer, Department of National Institute of Nursing Education, Postgraduate Institute of Medical Education and Research, Chandigarh, India, Phone: 9876055366, e-mail: karobi20@gmail.com

\section{Source of support: Nil}

Conflict of interest: None

\section{INTRODUCTION}

Blood is the essence of life, and is one of the most precious donations. Blood services are facing shortage of blood all over the world. Demand for blood is rising day by day and current blood donation is insufficient to meet the demand. ${ }^{1}$ The blood collection in India during 2011-2012 was 72.7 lakhs in comparison to the estimated requirement of 100 lakh units, thus the shortfall of 27.3 lakh units. ${ }^{2}$ Knowledge, attitude, and behavior studies have been done in many countries and despite the difference in demography and culture common outcomes have been noted including misinformation about blood donation, fear of blood donation, willingness to donate for only family or friends, concern about selling blood, and failure to transform positive attitude into actual donation as the main reasons among population. ${ }^{3}$ Most of the studies on blood donation were conducted in countries other than India. ${ }^{4-16}$ There are four studies on this subject from India, viz one each from Sikkim, Lucknow, Uttarakhand and South India. ${ }^{17-20}$ Thus, keeping in view the need to increase voluntary blood donation, the present study to assess the knowledge, attitude, and practices of blood donors was planned. The objectives of the study were to assess the knowledge, attitude, and practices of blood donors toward blood donation and to find out association of knowledge and attitude with selected demographic variables. In an attempt to achieve an absolute voluntary donation we must know what are the attitudes behind most of the blood donations and are these blood donation practices safe.

\section{MATERIALS AND METHODS}

The study was conducted at the Department of Transfusion Medicine of a tertiary level institute from northern India. The research approach adopted was nonexperimental survey which was descriptive in nature. Purposive sampling technique was used to select 60 blood donors. The data was collected during the month of April, 2012. The tool used for data collection was a self developed questionnaire on knowledge and expressed practices, along with a five point Likert scale for attitude. Knowledge questionnaire consisted of eleven questions related to knowledge about blood donation. The level of knowledge was classified 
as poor (0-2), average (3-5), good (6-8) and excellent (9-11). Likert scale for attitude consisted of twelve questions (6 positive and 6 negative) and was classified as strongly favorable $(>75 \%)$, favorable $(50-75 \%)$, and unfavorable $(<50 \%)$. Practice questionnaire consisted of 6 questions. The tool was administered to blood donors and paper pencil technique was used for data collection. Participants were given full autonomy to participate in the study and informed written consent was obtained. Collected data was analyzed using descriptive as well as inferential statistics.

\section{RESULTS}

Data on socioeconomic and demographic profile is presented in Table 1.

The data depicting knowledge of blood donors about blood donation is presented in Table 2, and shows the frequency and percentage of study subjects who correctly answered the knowledge related questions to blood donation. A total of 37 (61.7\%) blood donors were aware of their blood group and Rh factor. Encouragingly, 49 (81.7\%) and $52(86.77 \%)$ knew about different types of blood group and $\mathrm{Rh}$ factors, respectively. A total of 38 (63.3\%) donors had knowledge regarding type of patients who need blood transfusion, and $40(66.7 \%)$ donors were aware of the diseases those a person can acquire by receiving infected blood and

Table 1: Frequency and percentage distribution of subjects on the basis of their sociodemographic profile $(N=60)$

\begin{tabular}{ll}
\hline Sociodemographic characteristics & $\begin{array}{l}\text { Frequency } \\
(\%)\end{array}$ \\
\hline Gender & $59(98.3)$ \\
- Male & $1(1.7)$ \\
- Female & \\
Age (yrs) & $30(50)$ \\
- 18 to 27 & $14(23.3)$ \\
- 27 to 37 & $14(23.3)$ \\
- 37 to 47 & $2(3.4)$ \\
- 47 to 57 & \\
Marital status & $36(60)$ \\
- Married & $24(40)$ \\
- Unmarried & \\
Education & $1(1.7)$ \\
- Literate & $6(10)$ \\
- Secondary (10th) & $11(18.3)$ \\
- Senior secondary (12th) & $27(45)$ \\
- Graduate & $15(25)$ \\
- Postgraduate and above & \\
Occupation & $10(16.7)$ \\
- Professional & $12(20)$ \\
- Semi-professional & $11(18.3)$ \\
- Clerical/shop owner/farmer & $11(18.3)$ \\
- Semi-skilled worker & $16(26.7)$ \\
- Student & $14(23.3)$ \\
Monthly family income & $13(21.7)$ \\
- Below ₹ 5000 & $10(16.7)$ \\
- ₹ 5001 to 10000 & $23(38.3)$ \\
- ₹ 10001 to 20000 & \\
- ₹ 20001 and above & \\
\hline &
\end{tabular}

were familiar with the investigations that are done before donating blood. A total of 53 (88.3\%) of donors knew about number of times blood can be safely donated by a person.

The data depicting attitude toward blood donation for positive items is presented in Table 3; and shows that $50(90 \%)$ blood donors strongly agreed that blood donation saves life and $48(80 \%)$ of them also strongly agreed it to be a moral activity. A total of $40(66.6 \%)$ of blood donors strongly agreed while $16(26.6 \%)$ of them agreed that voluntary nonremunerated blood donation as the best way to donate blood. A total of 42 (70\%) of the participants strongly believed that every person should always disclose correct information about his/her health before donating blood.

The data presented in Table 4 shows item-wise distribution of responses of study subjects regarding their attitude toward blood donation for negative items. A total of $15(25 \%)$ blood donors were of the opinion that the best way to donate blood is at the request of relatives. A total of $46(76.6 \%)$ were strongly against and $10(16.7 \%)$ were against the opinion that best way to donate blood is paid donation. A total of 34 (56.7\%) blood donors strongly disagreed and 14 (23.3\%) disagreed that people who donate blood should receive something in exchange and were against the belief that people who donate blood are temporarily weakened. A total of 37 (61.6\%) of them strongly disagreed and $10(16.7 \%)$ disagreed that people who donate blood can contract disease. A total of $25(41.7 \%)$ strongly disagreed while 15 (25\%) disagreed with the view that they donate blood to get free investigations.

The data depicting practices of blood donation is presented in Table 5, and shows that majority (45,75\%) of the donors had donated blood for 1 to 5 times, and $3(5 \%)$ had donated for more than 25 times. Regarding the time interval between blood donations, nearly half $(46.7 \%)$ of donors donated blood only when they were asked. Regarding reasons for blood donation, exactly half $(50 \%)$ of them donated due to altruism, few (13.4\%) donated for replacement. On asking donors about their decision to donate blood in future, all (100\%) were willing to do so.

\section{Association of Knowledge with Selected Demographic Variables}

The knowledge of participants was found to be significantly associated with education and occupation at $\mathrm{p}<0.01$, so increase in education is associated with level of knowledge on blood donations and it also increased with professionalism.

\section{Association of Attitude with Selected Demographic Variables}

The attitude of blood donors toward blood donation was not associated with age, education and occupation. 


\begin{tabular}{|c|c|c|}
\hline $\begin{array}{l}\text { S. } \\
\text { no. }\end{array}$ & Items & $\begin{array}{l}\text { Frequency and percentage of correct } \\
\text { responses by respondents (\%) }\end{array}$ \\
\hline 1. & Are you aware of your blood group and Rh-factor? & $37(61.7)$ \\
\hline 2. & How many types of blood groups are there? & $49(81.7)$ \\
\hline 3. & What are the types of Rh-factors? & $52(86.7)$ \\
\hline 4. & Which blood group is a universal donor? & $44(73.3)$ \\
\hline 5. & Which blood group is a universal recipient? & $26(43.3)$ \\
\hline 6. & In which type of case patient needs blood transfusion? & $38(63.3)$ \\
\hline 7. & Which disease a person can acquire by receiving infected blood? & $40(66.7)$ \\
\hline 8. & How often blood can be safely donated by a person? & $53(88.3)$ \\
\hline 9. & Which age group can donate blood? & $15(25)$ \\
\hline 10. & $\begin{array}{l}\text { Are you aware about location of other local blood transfusion centers } \\
\text { apart from PGIMER? }\end{array}$ & $45(75)$ \\
\hline 11. & Which investigations are done before donating blood? & $40(66.7)$ \\
\hline
\end{tabular}

Table 3: Item wise distribution of response of subjects regarding attitude toward blood donation for positive items $(N=60)$

\begin{tabular}{|c|c|c|c|c|c|c|}
\hline \multirow{2}{*}{$\begin{array}{l}\text { S. } \\
\text { no. }\end{array}$} & \multirow[t]{2}{*}{ Items } & \multirow{2}{*}{$\begin{array}{l}\text { Strongly agree } \\
n(\%)\end{array}$} & \multirow{2}{*}{$\begin{array}{l}\text { Agree } \\
n(\%) \\
\end{array}$} & \multirow{2}{*}{$\begin{array}{l}\text { Uncertain } \\
n(\%)\end{array}$} & \multirow{2}{*}{$\begin{array}{l}\text { Disagree } \\
n(\%)\end{array}$} & \multirow{2}{*}{$\begin{array}{l}\text { Strongly disagree } \\
n(\%)\end{array}$} \\
\hline & & & & & & \\
\hline 1. & I think blood donation saves life & $54(90)$ & $06(10)$ & - & - & - \\
\hline 2. & $\begin{array}{l}\text { I think blood donation is a moral } \\
\text { activity }\end{array}$ & $48(80)$ & $10(16.7)$ & $02(3.3)$ & - & - \\
\hline 3. & $\begin{array}{l}\text { I think young people should } \\
\text { frequently donate blood rather } \\
\text { than old people }\end{array}$ & $47(78.3)$ & $10(16.7)$ & $02(3.3)$ & - & $01(1.7)$ \\
\hline 4. & $\begin{array}{l}\text { I think people having more } \\
\text { knowledge on blood donation } \\
\text { donate more often }\end{array}$ & $34(56.7)$ & $21(35)$ & $03(5)$ & $02(3.3)$ & - \\
\hline 5. & $\begin{array}{l}\text { In my opinion the best way to } \\
\text { donate blood is voluntary non } \\
\text { remunerated }\end{array}$ & $40(66.6)$ & $16(26.7)$ & $02(3.3)$ & $01(1.7)$ & $01(1.7)$ \\
\hline 6. & $\begin{array}{l}\text { I think every person should } \\
\text { always disclose correct } \\
\text { information about his/her health } \\
\text { before donating blood }\end{array}$ & $42(70)$ & $16(26.6)$ & $01(1.7)$ & - & $01(1.7)$ \\
\hline
\end{tabular}

\section{DISCUSSION}

The findings of the present study have revealed that most of the blood donations $(96.6 \%)$ were done by people who were in age group of 18 to 27 followed by 27 to 47 years. Gender-wise greater proportion of the blood donors were males $98.3 \%$ than females and these finding are comparable with the study conducted in Sikkim and Uttarakhand (84\% and $84.2 \%$ respectively). ${ }^{17,20}$ These both findings are also consistent to the report of WHO Global Database on Blood Safety, 2008. It was reported that in the low and middleincome countries most of the blood donations are done by people in age group of 18 to 24 and 25 to 44 years, whereas in high income countries, it is made by people aged over 44 years. Out of 100 countries overall, just $30 \%$ of blood donations are given by women. ${ }^{21}$

Related to the knowledge of blood donors in present study the mean knowledge score and mean percentage was $6.21 \pm 2.3$ and $51.8 \%$, respectively. This means that they had good knowledge and these findings are consistent with the findings of Wiwanitkit et al, ${ }^{5}$ Mousavi et al, ${ }^{11}$ Shenga
$\mathrm{N}$ et al, ${ }^{17}$ and Sabu et al. ${ }^{18}$ In the present study, all of the participants said that they would donate in future whereas in a study conducted by Dubey et al, ${ }^{19} 57.3 \%$ said that they would donate only if a need arose in their family or friends and surprisingly $13.3 \%$ people said that they would not like to donate ever in their lifetime.

The findings of the present study also revealed that $86 \%$ participants had a positive attitude toward blood donation. Similar findings are reported by Abdel et al ${ }^{8}$ in which $99 \%$ of the respondents from Saudi Arabia showed positive attitude toward blood donations and its importance for patients' care. Hossain et $\mathrm{al}^{6}$ and Okpara et $\mathrm{al}^{13}$ also reported that $82 \%$ participants form Dhaka, Bangladesh and 79.7\% from Nigeria, respectively, had positive attitude. However, 28 (46.7\%) participants said that they donated blood only when they were asked for it. The WHO 2008 report also documented that low and middle income countries rely mostly on family or replacement donors. ${ }^{21}$

The present study has revealed that there was a significant association between the level of knowledge of blood 
donors with education and occupation. These findings are in accordance with a study conducted by Shenga $\mathrm{N}$ et al. ${ }^{17}$ Level of knowledge on blood donation was also found to be associated with education in a study conducted by Mousavi et al. ${ }^{11}$ Whereas Wiwanitkit et al reported that it was not associated with educational level. ${ }^{5}$ In the present study, the level of knowledge was not associated with age and gender. Whereas some studies support, while others did not find any association of age and gender with knowledge. ${ }^{5,11,17,18}$

Table 4: Item wise distribution of responses of study subjects regarding their attitude toward blood donation for negative items $(N=60)$

\begin{tabular}{|c|c|c|c|c|c|c|}
\hline \multirow{2}{*}{$\begin{array}{l}\text { S. } \\
\text { no. }\end{array}$} & \multirow[t]{2}{*}{ Items } & Strongly agree & Agree & Uncertain & Disagree & Strongly disagree \\
\hline & & $n(\%)$ & $n(\%)$ & $n(\%)$ & $n(\%)$ & $n(\%)$ \\
\hline 1. & $\begin{array}{l}\text { In my opinion the best way to } \\
\text { donate blood is at the request of } \\
\text { relatives }\end{array}$ & $15(25)$ & $3(5)$ & $4(6.7)$ & $21(35)$ & $17(28.3)$ \\
\hline 2. & $\begin{array}{l}\text { In my opinion the best way to } \\
\text { donate blood is paid donation }\end{array}$ & $1(1.7)$ & $1(1.7)$ & $2(3.3)$ & $10(16.7)$ & $46(76.6)$ \\
\hline 3. & $\begin{array}{l}\text { I think people who donate blood } \\
\text { should receive something in } \\
\text { exchange }\end{array}$ & $3(5)$ & $3(5)$ & $6(10)$ & $14(23.3)$ & $34(56.7)$ \\
\hline 4. & $\begin{array}{l}\text { I think people who donate blood } \\
\text { can contract disease }\end{array}$ & $2(3.3)$ & $4(6.7)$ & $7(11.7)$ & $10(16.7)$ & $37(61.6)$ \\
\hline 5. & $\begin{array}{l}\text { I think people who donate blood } \\
\text { are temporarily weakened }\end{array}$ & $1(1.7)$ & $8(13.3)$ & $9(15)$ & $8(13.3)$ & $34(56.7)$ \\
\hline 6. & $\begin{array}{l}\text { I donate blood to get free } \\
\text { investigations }\end{array}$ & $8(13.3)$ & $9(15)$ & $3(5)$ & $15(25)$ & $25(41.7)$ \\
\hline
\end{tabular}

Table 5: Frequency and percentage distribution of blood donors according to their practice toward blood donation

\begin{tabular}{|c|c|}
\hline Practice related to blood donation & $N=60(\%)$ \\
\hline \multicolumn{2}{|l|}{ Number of blood donations } \\
\hline - $1-5$ times & $45(75)$ \\
\hline - 6-10 times & $7(11.7)$ \\
\hline - 11-15 times & $2(3.3)$ \\
\hline - 16-20 times & $1(1.7)$ \\
\hline$-21-25$ times & $2(3.3)$ \\
\hline - Above 25 times & $3(5)$ \\
\hline \multicolumn{2}{|l|}{ Any blood donations by family members } \\
\hline- Yes & $30(50)$ \\
\hline- No & $30(50)$ \\
\hline \multicolumn{2}{|l|}{ Frequency of donating blood } \\
\hline - Every three months & $16(26.7)$ \\
\hline - Every six months & $8(13.3)$ \\
\hline - Once in a year & $8(13.3)$ \\
\hline - Only when asked for & $28(46.7)$ \\
\hline \multicolumn{2}{|l|}{ Started donating blood at the age of } \\
\hline - Less than 20 years & $17(28.3)$ \\
\hline - 21 to 30 years & $32(53.3)$ \\
\hline - 31 to 40 years & $8(13.4)$ \\
\hline - 41 to 50 years & $2(3.3)$ \\
\hline - More than 50 years & $1(1.7)$ \\
\hline \multicolumn{2}{|l|}{ Reasons of donating blood } \\
\hline - Peer and relative's pressure (replacement) & $8(13.4)$ \\
\hline - Self motivation & $11(18.3)$ \\
\hline $\begin{array}{l}\text { - Altruism/unselfish concern for the welfare } \\
\text { of the other }\end{array}$ & $30(50)$ \\
\hline - All of the above & $11(18.3)$ \\
\hline \multicolumn{2}{|l|}{ Whether you will donate blood in future? } \\
\hline- Yes & $60(100)$ \\
\hline$-\mathrm{No}$ & $0(0)$ \\
\hline
\end{tabular}

\section{CONCLUSION}

We can conclude that although blood donors had good knowledge and positive attitude still many of them were donating blood only when they were asked for, and not regularly. Hence, we need to think of measures to encourage people to donate more and more blood voluntarily and regularly so as to achieve WHO goal of $100 \%$ voluntary blood donation by 2020 .

\section{REFERENCES}

1. Horton R. Blood supply and demand. Lancet 2005;365:2151.

2. Blood Safety. Annual 2011-2012, Department of AIDS control, National AIDS Control Organisation, Ministry of Health and Family Welfare, Government of India. Available from: http:// www.nacoonline.org/ upload/ report/NACO\% 20Annual\%20 report\%202010-11.pdf.[Last accessed on 2013 April 4].

3. Lownik E, Riley E, Konstenius T, Riley W, McCullough J. Knowledge, attitudes and practices surveys of blood donation in developing countries. Vox Sang 2012;103(1):64-74.

4. Sampath S, Ramsaran V, Parasram S, Mohammed S, Latchman S, Khunja R, Budhoo D, Poon King C, Charles KS. Attitudes towards blood donation in Trinidad and Tobago. Transfus Med 2007; 17(2):83-87.

5. Wiwanitkit V. Knowledge about blood donation among a sample of Thai university students. Vox Sang 2002;83(2):97-99.

6. Hosain GM, Anisuzzaman M, Begum A. Knowledge and attitude towards voluntary blood donation among Dhaka University students in Bangladesh. East Afr Med J 1997;74(9):549-553.

7. Javadzadeh Shahshahani H, Yavari MT, Attar M, Ahmadiyeh MH. Knowledge, attitude and practice study about blood donation in the urban population of Yazd, Iran, 2004. Transfus Med 2006; 16(6):403-409. 
8. Abdel Gader AG, Osman AM, Al Gahtani FH, Farghali MN, Ramadan AH, Al-Momen AK. Attitude to blood donation in Saudi Arabia. Asian J Transfus Sci 2011;5(2):121-126.

9. Buciuniene I, Stonienë L, Blazeviciene A, Kazlauskaite R, Skudiene V. Blood donors' motivation and attitude to nonremunerated blood donation in Lithuania. BMC Public Health 2006;6:166.

10. Fernández Montoya A, de Dios Luna del Castillo J, López Berrio A, Rodríguez Fernández A. Attitudes, beliefs, and motivations in blood donors and non-donors. Sangre (Barc) 1996;41(6):427-440.

11. Mousavi F, Tavabi AA, Golestan B, Ammar-Saeedi E, Kashani H, Tabatabaei R, Iran-Pour E. Knowledge, attitude and practice towards blood donation in Iranian population. Transfus Med 2011;21(5):308-317.

12. Olaiya MA, Alakija W, Ajala A, Olatunji RO. Knowledge, attitudes, beliefs and motivations towards blood donations among blood donors in Lagos, Nigeria. Transfus Med 2004;14(1):13-17.

13. Okpara RA. Attitudes of Nigerians towards blood donation and blood transfusion. Trop Geogr Med 1989;41(1):89-93.

14. Ben Natan M, Gorkov L. Investigating the factors affecting blood donation among Israelis. Int Emerg Nurs 2011;19(1): $37-43$.
15. Godin G, Conner M, Sheeran P, Bélanger-Gravel A, Germain M. Determinants of repeated blood donation among new and experienced blood donors. Transfusion 2007;47(9):1607-1615.

16. Glynn SA, Williams AE, Nass CC, Bethel J, Kessler D, Scott EP, Fridey J, Kleinman SH, Schreiber GB. Attitudes toward blood donation incentives in the United States: implications for donor recruitment. Transfusion 2003;43(1):7-16.

17. Shenga N, Pal R, Sengupta S. Behavior disparities towards blood donation in Sikkim, India. Asian J Transfus Sci 2008;2(2): 56-60.

18. Sabu KM, Remya A, Binu VS, Vivek R. Knowledge, attitude and practice on blood donation among health science students in a university campus, South India. Online J Health Allied Sci 2011;10(2):6.

19. Dubey A, Sonker A, Chaurasia R, Chaudhary R. Knowledge, attitude and beliefs of people in North India regarding blood donation. Blood Transfus 2014;12(Suppl 1):21-27.

20. Agrawal A, Tiwari AK, Ahuja A, Kalra R. Knowledge, attitude and practices of people towards voluntary blood donation in Uttarakhand. Asian J Transfus Sci 2013;7(1):59-62.

21. WHO. Global database on blood safety. Available From: http:// www.who.int/bloodsafety/global_database/en/index.html. [Last accessed on 2013 April 4]. 